\title{
Catalytic properties of graphitic and pyridinic nitrogen doped on carbon black for oxygen reduction reaction
}

\author{
Jing Liu a,b, Ping Song a, Mingbo Ruan a, Weilin Xu a,* \\ a State Key Laboratory of Electroanalytical Chemistry, Jilin Province Key Laboratory of Low Carbon Chemical Power, Changchun Institute of Applied \\ Chemistry, Chinese Academy of Sciences, Changchun 130022, Jilin, China \\ ${ }^{\mathrm{b}}$ University of Chinese Academy of Sciences, Beijing 100049, China
}

\section{A R T I C L E I N F O}

Article history:

Received 20 March 2016

Accepted 11 May 2016

Published 5 July 2016

Keywords:

Carbon black

Heat-treatment

Oxygen reduction reaction

Nitrogen doping

Carbon-based catalysts
A B S T R A C T

Pure graphitic nitrogen (G-N) was doped on carbon black by Hummers method and a following heat treatment was used to transform the G-N to pyridinic (P)-N. An oxygen reduction reaction (ORR) study showed that the G-N site doped on carbon gave a two-electron ORR with $\mathrm{H}_{2} \mathrm{O}_{2}$ as the main product, while the P-N site gave the four-electron process of ORR and decreased the production of $\mathrm{H}_{2} \mathrm{O}_{2}$. The results help the understanding and design of doped N-based ORR electrocatalysts.

(C) 2016, Dalian Institute of Chemical Physics, Chinese Academy of Sciences. Published by Elsevier B.V. All rights reserved.

\section{Introduction}

Exploring efficient electrocatalysts for the sluggish oxygen reduction reaction (ORR) is desirable for the commercialization of fuel cells [1] and metal-air batteries [2]. In the past decade, intensive studies have been done to develop low cost, high efficient ORR electrocatalysts, such as the doped N-based metal-free and Pt-free electrocatalysts [3,4]. Concerning the active sites on $\mathrm{N}$-doped carbon materials for ORR, there are four types of N-based active sites, namely, pyridinic N (P-N), pyrrolic $\mathrm{N}(\mathrm{Py}-\mathrm{N})$, graphitic $\mathrm{N}(\mathrm{G}-\mathrm{N})$ and oxidized $\mathrm{N}(\mathrm{O}-\mathrm{N})$ [5]. In spite of extensive studies, the structure-activity relationship or catalytic mechanism on the different $\mathrm{N}$-containing active sites on carbon is still not clear. Debated questions related to the catalytic activity of different $\mathrm{N}$-containing groups still exist
$[6,7]$. Some experimental data showed that P-N and Py-N were catalytically active [8-13], while others indicated that G-N was active [14-18]. Some reports claimed that both P-N and G-N contributed to the catalytic property but with different roles $[6,19]$. These observations suggested that to get clear understanding of these N-containing active sites for ORR, it is desirable to get the structure-activity relationship of different doped N-based active sites on carbon. For this goal, some clean models with only one type of $\mathrm{N}$ doped site have been reported. In 2013, Wei's group [20] reported a selective synthesis of P-N and Py-N-doped graphene and showed that the pyridinic and pyrrolic sites with a planar structure were catalytically active for the ORR. Qiao's group [7] further showed that the carbon atoms close to P-N were the main active sites among the different nitrogen doping configurations.

\footnotetext{
* Corresponding author. Tel/Fax: +86-431-85262848; E-mail: weilinxu@ciac.ac.cn

This work was supported by the National Basic Research Program of China (973 Program, 2012CB932800, 2014CB932700), the National Natural Science Foundation of China (21422307, 21303180, 21433003, 21503212, 21503211), and the "Recruitment Program of Global Youth Experts" of China.
} 
In this work, we used a common carbon black, Vulcan XC-72 (VXC-72) and an acid oxidation (Hummers method) treatment [21] and showed that the Hummers acid oxidation treatment led to pure G-N doping on carbon, and a following heat treatment led to Py-N doping with adsorbed $\mathrm{NO}_{3}{ }^{-}$or $\mathrm{NO}_{2}{ }^{-}$as the $\mathrm{N}$

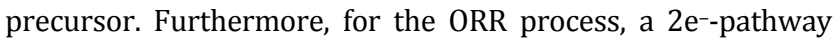
with $\mathrm{H}_{2} \mathrm{O}_{2}$ as the main product was found on the G-N-based active sites while a $4 \mathrm{e}^{-}$-pathway existed on Py-N sites with water as the main product, which was consistent with a recent report [22].

\section{Experimental}

\subsection{Sample preparation}

The oxidization of VXC-72 was performed by Hummers method [21]. The Vulcan XC-72 was purchased from E-TEK Company. USA. $\mathrm{H}_{2} \mathrm{SO}_{4}, \mathrm{NaNO}_{3}, \mathrm{KMnO}_{4}, \mathrm{H}_{2} \mathrm{O}_{2}$ (30\%), $\mathrm{HCl}$ and $\mathrm{KOH}$ were purchased from Beijing Chemical Works. Nafion solution (5 wt\%) was obtained from Sigma-Aldrich. All chemicals were used without further treatment. Ultrapure water with a specific resistance of $18.23 \mathrm{M} \Omega \cdot \mathrm{cm}$ was obtained by reversed osmosis followed by ion exchange and filtration. The once and twice oxidation products were denoted as VXCO-1 and VXCO-2, respectively. VXCO-1 was prepared by stirring $1.0 \mathrm{~g} \mathrm{VXC-72}$ powder and $0.5 \mathrm{~g} \mathrm{NaNO}_{3}$ into $23.0 \mathrm{~mL}$ concentrated sulfuric acid (98\%). The ingredients were mixed in a $500.0 \mathrm{~mL}$ round-bottomed flask that had been cooled to 0 ${ }^{\circ} \mathrm{C}$ in an ice bath. While maintaining vigorous agitation, $3.0 \mathrm{~g}$ $\mathrm{KMnO}_{4}$ was carefully added to the suspension. The ice bath was then removed and the suspension was heated to $35^{\circ} \mathrm{C}$, where it was maintained for $60 \mathrm{~min}$. After that, $46.0 \mathrm{~mL}$ water was slowly dropped into the flask, causing violent effervescence and an increase in temperature to $98{ }^{\circ} \mathrm{C}$. The mixture was further stirred for $30 \mathrm{~min}$. Finally, $140.0 \mathrm{~mL}$ distilled water and 10.0 $\mathrm{mL} \mathrm{H}_{2} \mathrm{O}_{2}$ were added dropwise and the reaction was terminated. The generated solid VXCO-1 was separated by centrifugation, washed and finally dried under vacuum. The further oxidized product VXCO-2 was based on VXCO-1 formed by the same Hummer method. VXC-72, VXCO-1 and VXCO-2 were then subjected to thermal treatment at $900{ }^{\circ} \mathrm{C}$ under $\mathrm{N}_{2}$, which were denoted as VXC-72(900), VXCO-1(900) and VXCO-2(900), respectively. VXCO-1 was also subjected to a thermal treatment at 800 and $1000{ }^{\circ} \mathrm{C}$ under $\mathrm{N}_{2}$ gas, which were denoted as VXCO-1(800) and VXCO-1(1000), respectively. The resulting black powder was carefully collected because the products had a low mass density and was very easily blown away.

\subsection{Characterization}

The morphology and dimensions of the samples were obtained using a field emission scanning electron microscope (SEM) (XL30) operated at an accelerating voltage of $10 \mathrm{kV}$. BET surface areas (АВЕT) and pore volumes were obtained from $\mathrm{N}_{2}$ adsorption-desorption isotherms using an ASAP 2020 instrument at $-196{ }^{\circ} \mathrm{C}$. The $\mathrm{N}$ content in the catalysts were obtained from elemental analysis (EA, Vario EL CUBE, Elementar). X-ray photoelectron spectroscopic (XPS) measurements were performed on an AXIS Ultra DLD (Kratos company) using a monochromic Al X-ray source. The Raman spectrum was obtained on a laser confocal Raman spectroscopy (Labram-010, Horiba-JY) employing the Nd: YAG laser wavelength of $633 \mathrm{~nm}$. X-ray diffraction (XRD) patterns were obtained on a D8 ADVANCE (Bruker company, Germany), using filtered $\mathrm{Cu} \mathrm{K \alpha}$ radiation $(40 \mathrm{kV}, 30 \mathrm{~mA})$.

\subsection{Electrochemical measurements}

The electrochemical performance was conducted in 0.1 mol/L $\mathrm{KOH}$ solution. The counter and reference electrodes were a platinum wire and SCE electrode, respectively. The potential of the electrode was controlled by a CHI 750E system (CH Instrument Co., USA). Cyclic voltammetry (CV) was performed from 0.2 to $-1.2 \mathrm{~V}$ at $50 \mathrm{mV} / \mathrm{s}$ after purging the electrolyte with $\mathrm{O}_{2}$ or $\mathrm{N}_{2}$ for $30 \mathrm{~min}$. Linear sweep voltammetry (LSV) measurements were performed using a rotating disk electrode (RDE) at different rotating speeds from 225 to $1600 \mathrm{r} / \mathrm{min}$ in an $\mathrm{O}_{2}$ saturated electrolyte from 0.2 to $-1.2 \mathrm{~V}$ (vs. SCE) at a sweep rate of $5 \mathrm{mV} / \mathrm{s}$ in $\mathrm{O}_{2}$ saturated $\mathrm{KOH}$ solution $(0.1 \mathrm{~mol} / \mathrm{L})$. For the RRDE measurements, the disk electrode sweep was from 0.2 to $-1.2 \mathrm{~V}$ vs. SCE while the Pt ring potential was kept at $0.5 \mathrm{~V}$ vs. SCE at a scan rate of $5 \mathrm{mV} / \mathrm{s}$ after $\mathrm{O}_{2}$ was purged for about $30 \mathrm{~min}$ into the $\mathrm{KOH}$ solution $(0.1 \mathrm{~mol} / \mathrm{L})$. The percentage of $\mathrm{HO}_{2}-$ generated from the ORR and the electron transfer number $(n)$ were estimated by the following equations [23]:

$$
\begin{gathered}
\mathrm{HO}_{2}^{-} \%=200 \times \frac{i_{\mathrm{R}} / M}{i_{\mathrm{D}}+i_{\mathrm{R}} / M} \\
n=4 \times \frac{i_{\mathrm{D}}}{i_{\mathrm{D}}+i_{\mathrm{R}} / M}
\end{gathered}
$$

where $i_{\mathrm{D}}$ is the disk current density, $i_{\mathrm{R}}$ is the ring current density and $M$ is the current collection efficiency of the Pt ring disk. $M$ was 0.37 from the reduction of $\mathrm{K}_{3} \mathrm{Fe}[\mathrm{CN}]_{6}$.

All the current densities were normalized to the electrode surface area. All electrochemical experiments were carried out at room temperature.

\section{Results and discussion}

\subsection{Catalyst characterization}

As shown in Fig. 1(a), after the reaction, the supernatant containing small pieces of graphene oxide (GO) was discarded. The obtained precipitant was either washed directly with a large amount of water by repeated sonication and centrifugation until $\mathrm{pH} \approx 7$ or re-oxidized one more time. The water-washed samples (VXCO-1 and VXCO-2, representing the samples obtained after one or two acid oxidation, respectively) were then heated at $900{ }^{\circ} \mathrm{C}$ for three hours under flowing $\mathrm{N}_{2}$ to get the final heat treated samples (VXCO-1(900) and VXCO-2(900)). SEM analysis showed that the surface of the carbon nanoparticles became smoother after the acid treatment. The flatness of the surface was in the order: VXCO-2 > VXCO-1 > VXC-72. This result was consistent with the $A_{\mathrm{BET}}$ 

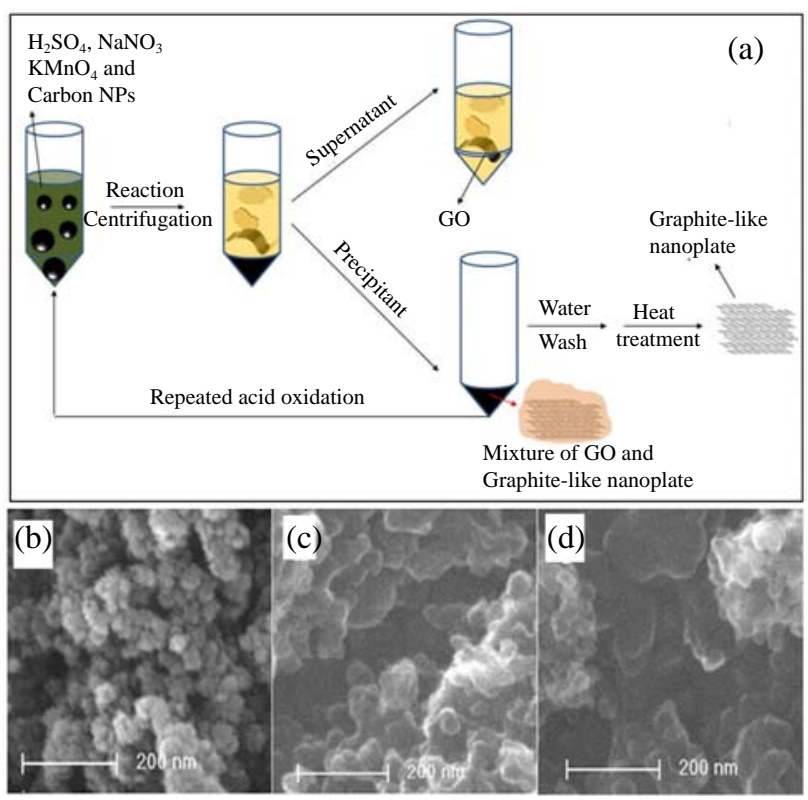

Fig. 1. (a) Scheme showing the preparation of once or twice acid oxidized carbon samples with and without a following heat treatment. Typical SEM images for the VXC-72 with average size of $35 \pm 4 \mathrm{~nm}$ (b), VXCO- 1 with average size of $55 \pm 3 \mathrm{~nm}$ (c), and VXCO-2 with average size of $70 \pm 5 \mathrm{~nm}(\mathrm{~d})$.

analysis. As shown in Table 1, after the first and second oxidation treatment, $A_{\text {BET }}$ decreased from 204.1 (VXC-72) to 179.9 (VXCO-1), and then to 65.9 (VXCO-2). Moreover, these SEM images showed clearly that the carbon nanoparticles became bigger after the acid treatment (from 35 to $55 \mathrm{~nm}$, then to 70 $\mathrm{nm})$. The increase of particle size may be due to the arrangement of small carbon particles into agglomerates [24]. In addition, the morphology change of the carbon nanoparticles can be attributed to the Hummers method used, which has been used extensively to peel off single/few-layered graphene oxide (GO) from a graphite surface layer-by-layer [21].

Due to the layered structure of the carbon nanoparticles shown in Scheme 1(a), the tiny graphene layers on the carbon nanoparticle surface will be peeled off one-by-one. Then the exposed surface of the remaining carbon nanoparticles becomes smoother and larger, and some graphite-like carbon nanoplates was obtained. With the multiple peeling-off cycles, some tiny carbon nanoparticles will be completely peeled into GO pieces and were lost. Most of the GO obtained was removed in the following washing step since these tiny GO could not be centrifuged at $10000 \mathrm{r} / \mathrm{min}$. In this way, the tiny spherical car-

Table 1

Nitrogen content, $I_{\mathrm{G}} / I_{\mathrm{D}}, A_{\mathrm{BET}}, E_{\text {onset, }} \mathrm{HO}_{2}{ }^{-}$concentration, and number of electrons transferred $(n)$ in different samples.

\begin{tabular}{lcrrccc}
\hline Sample & $\begin{array}{c}\mathrm{N} \\
(\mathrm{wt} \%)\end{array}$ & $\begin{array}{c}A_{\mathrm{BET}} \\
\left(\mathrm{m}^{2} / \mathrm{g}\right)\end{array}$ & $I_{\mathrm{G}} / I_{\mathrm{D}}$ & $\begin{array}{c}E_{\text {onset }} \\
(\mathrm{mV} \text { vs. SCE })\end{array}$ & $\begin{array}{c}\mathrm{HO}_{2}{ }^{-} \\
(\%)\end{array}$ & $n$ \\
\hline VXC-72 & - & 204.1 & 0.596 & -219 & 49.6 & 3 \\
VXC0-1 & 0.31 & 179.9 & 0.634 & -165 & 71.6 & 2.6 \\
VXC0-2 & 0.29 & 65.9 & 0.667 & -180 & 73.9 & 2.5 \\
VXC0-1(900) & 0.20 & 256.4 & 0.608 & -217 & 55.1 & 2.9 \\
VXC0-2(900) & 0.22 & 140.5 & 0.642 & -218 & 63.6 & 2.7 \\
\hline
\end{tabular}

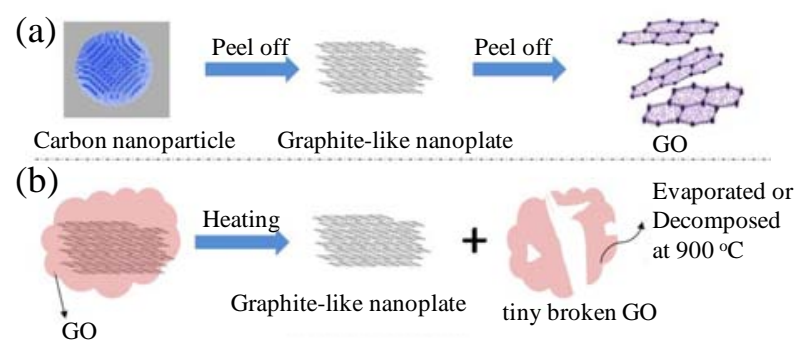

Scheme 1. (a) Peeling of carbon nanoparticles with Hummers method. Some tiny nanoparticles are completely transformed into tiny GO. (b) Removing of GO covering from the graphite-like carbon nanoplate surface to expose more surface area during the heat treatment.

bon nanoparticles disappeared and some flat surface graphite-like large carbon nanoplates remained. This was the reason why the remaining carbon nanoparticles became larger and flatter after the acid treatment.

The formation of the flat surface graphite-like structure was also confirmed by the Raman spectra shown in Fig. 2. The D (related to defects) and G (related to graphite-like structure) bands, which are the two characteristic peaks of graphite, were clearly seen in all of these samples at $\sim 1300$ and $1600 \mathrm{~cm}^{-1}$, respectively [25]. After the first and second oxidation treatment, the intensity ratio of the G- and D-bands $\left(I_{G} / I_{D}\right)$ increased slightly from 0.596 (VXC-72) to 0.634 (VXCO-1), and finally to 0.667 (VXCO-2), which confirmed the formation of a graphite-like structure in the VXCO-1 and VXCO-2 samples (Table1). The increase of graphitized degree after the acid treatment was further confirmed on XRD. As shown in Fig. 3, the three VXC-72, VXCO-1 and VXCO-1(900)samples exhibited two peaks at $25^{\circ}$

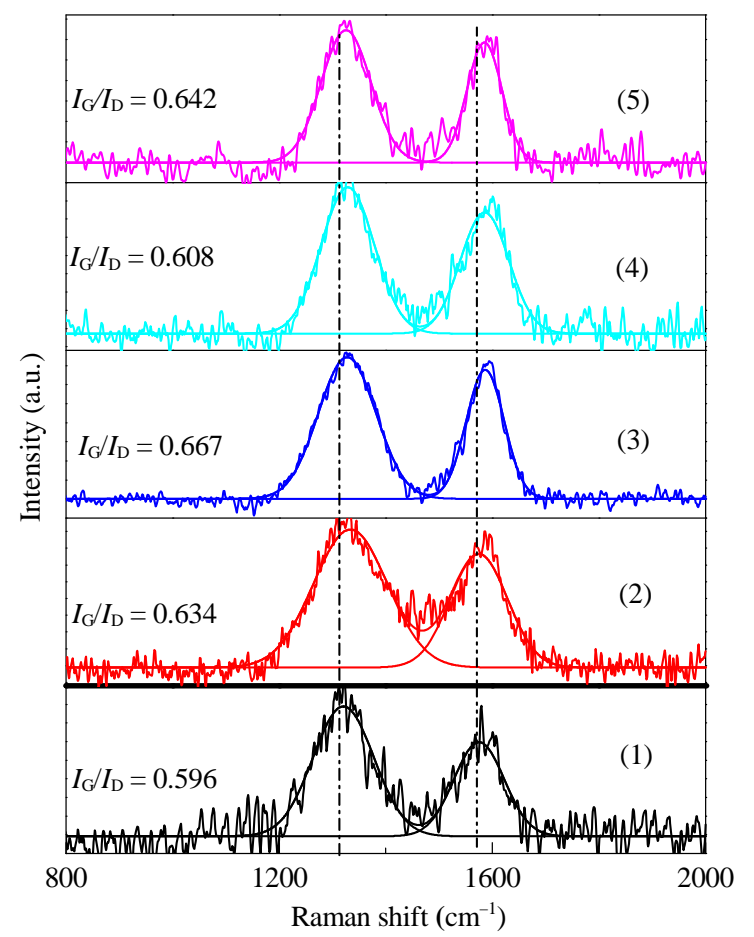

Fig. 2. Raman spectra of VXC-72 (1), VXCO-1 (2), VXCO-2 (3), VXCO-1(900) (4), and VXCO-2(900) (5). 


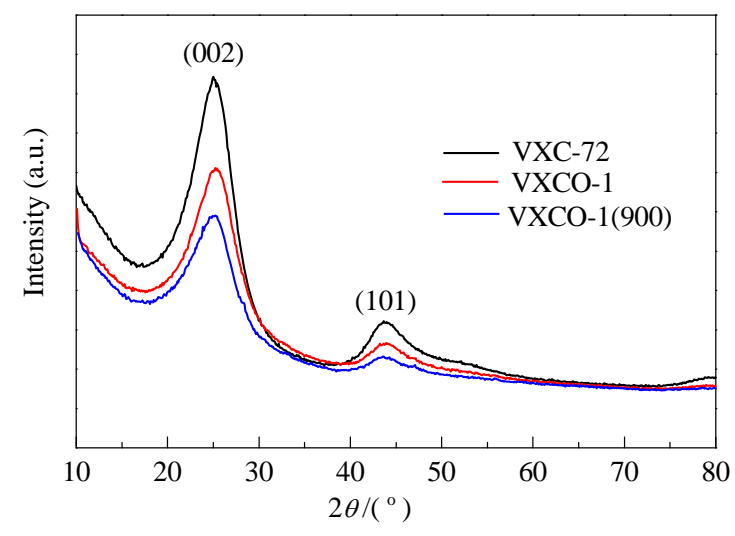

Fig. 3. XRD patterns of VXC-72, VXCO-1, and VXCO-1(900).

and $43^{\circ}$ corresponding to the (002) and (101) planes of the graphitic structure. The (002) diffraction peak of VXCO-1 was shifted towards a higher value compared to VXC-72, suggesting the (002) interplanar distance in VXCO-1 was smaller than that in VXC-72. In other words, the graphitic structure of VXCO-1 was larger than that of VXC-72, which was consistent with the Raman analysis [26].

Furthermore, unexpectedly, it was found that a heat treatment at $900{ }^{\circ} \mathrm{C}$ increased the $A_{\text {BET }}$ of these acid treated samples as shown in Table 1. From the adsorption isotherm of the carbon materials before and after the heat treatment (Fig. 4), we can see that the $A_{\mathrm{BET}}$ increase after the heat treatment (VXCO-1(900)) can be partially attributed to the formation of smaller $(50 \mathrm{~nm})$ pores compared with those $(100 \mathrm{~nm})$ in VXCO-1 [24]. For VXCO-2, Figs. 4 and 5 did not show much dif-

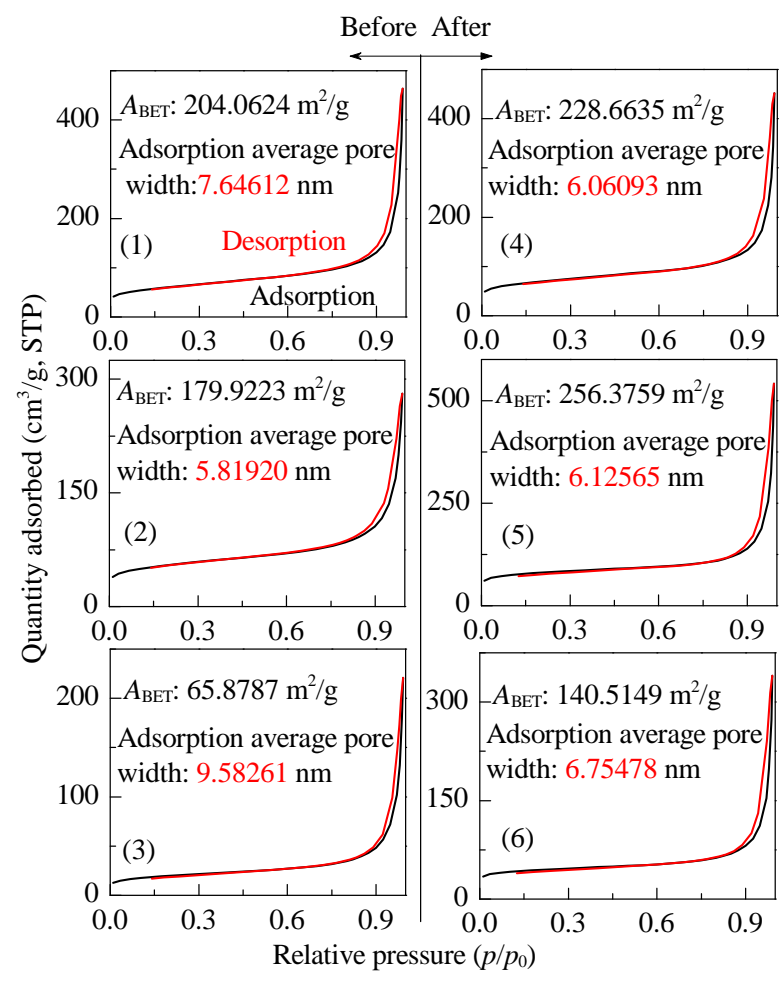

Fig. 4. Adsorption-desorption isotherms of VXC-72 (1), VXCO-1 (2), VXCO-2 (3), VXC-72(900) (4), VXCO-1(900) (5), and VXCO-2(900) (6).

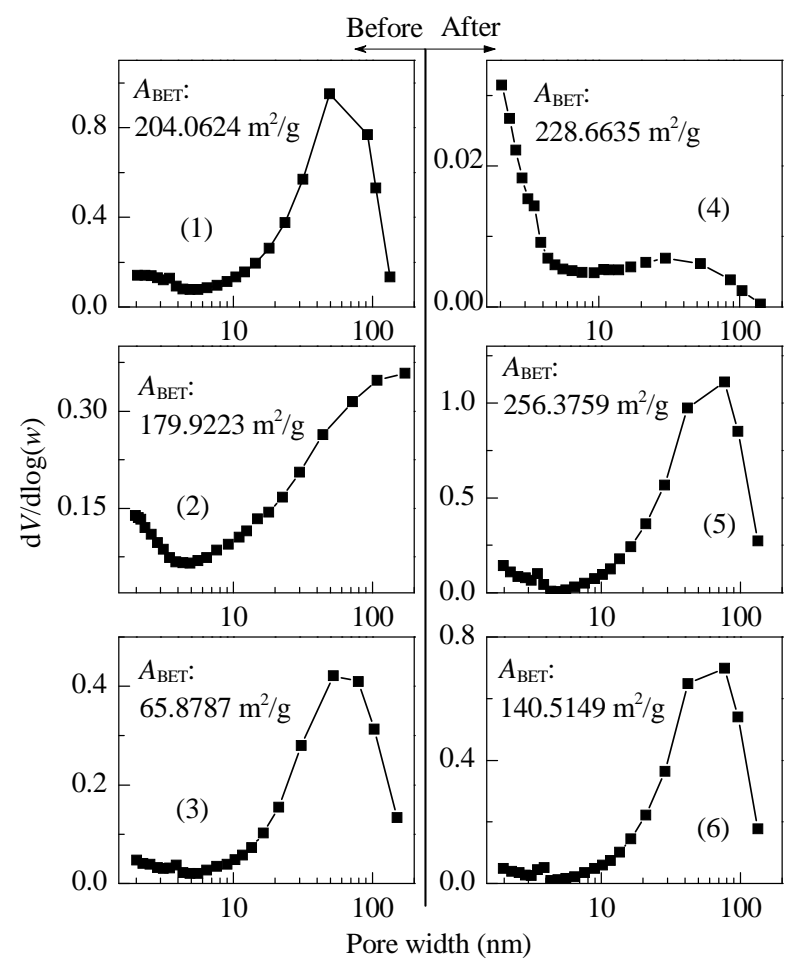

Fig. 5. Pore size distribution of VXC-72 (1), VXCO-1 (2), VXCO-2 (3), VXC-72(900) (4), VXCO-1(900) (5), and VXCO-2(900) (6).

ference in the pore size distribution between VXCO-2 and VXCO-2 (900), but the AвEт increased more than two times (from 65.88 to $140.51 \mathrm{~m}^{2} / \mathrm{g}$ ) after the heat treatment. This was different compared with that which occurred on VXCO-1. So what was the reason for this? In order to get some clues, we looked back at the method of the acid pretreatment: Hummers method, which is usually used to peel off single/few-layered GO from graphite [21]. Due to this special acid oxidation method, we need to consider the effect of some residual large GO after the water washing. With the acid treatment, the surface layers of the carbon nanoparticles were peeled into single or few-layered GO. Most of these GO pieces in the supernatant were removed in the washing step with centrifugation (Fig. 1(a)). However, some larger GO pieces remained in the precipitate and covered some surface of the remaining graphite-like nanoplates, like that shown in Scheme 1(b). During the heat treatment at $900{ }^{\circ} \mathrm{C}$, these tiny flat surface graphene layers can be easily removed from the carbon nanoparticle surface by evaporation (just like $\mathrm{C}_{60}$ ) [27] or the decomposition of tiny graphene layers into smaller pieces (Scheme 1(b)), and a rougher surface (steps or edges) of carbon was exposed. The phenomena can also confirmed by the decrease of the value of $I_{G} / I_{D}$ from 0.634 (VXCO-1) and 0.667 (VXCO-2) to 0.608 (VXCO-1(900)) and 0.642 (VXCO-2(900)) (Fig. 2, Table 1), which indicated a decrease of the graphitized degree of the carbon materials [25]. This would explain the increase of ABET observed after the heat treatment on acid pre-treated carbon samples. Interestingly, the decrease of graphitized degree after the heat treatment was also observed by XRD (Fig. 3). The (002) diffraction peak of VXCO-1(900) was shifted towards a 
lower value compared to primary VXCO-1, suggesting the (002) interplanar distance in VXCO-1(900) was larger than that of VXCO-1. This further indicated that the graphitic structure of VXCO-1(900) was smaller than that of VXCO-1.

ICP was used to detect possible metal residuals. Interestingly, no metal (such as $\mathrm{Mn}, \mathrm{K}, \mathrm{Na}, \mathrm{Fe}$, Co or $\mathrm{Ni}$ ) was detected in these carbon samples, indicating that the washing of the sample after the oxidation reaction was very thorough and removed any byproducts of metal ions. High resolution XPS spectra were used to determine the chemical states of the non-metal elements on the surface of these samples. The $\mathrm{N}$ content in the catalysts was obtained by elemental analysis. As shown in Table 1, no N was detected on the raw carbon VXC-72. After the acid treatment, a trace amount of $\mathrm{N}$ was detected, ever after the heat treatment (Table 1 and Fig. 6) [28]. As shown in Fig. 2, the positive shift of the Raman peaks (D and G peaks) of VXCO-1 and VXCO-2, compared to those of VXC-72, indicated the occurrence of electron transfer due to the introduction of $\mathrm{N}$. Thus this further confirmed the formation of N-containing carbon materials [25].

Fig. 6(a) and (b) show that there were two different states of $\mathrm{N}$ on the acid-treated samples (VXCO-1 and VXCO-2). One was oxidized $\mathrm{N}(\sim 35 \%)$ mainly due to residual $\mathrm{NO}_{3}{ }^{-}$adsorbed on the carbon nanoparticles with a binding energy of $405.4 \mathrm{eV}$ (on VXCO-1) or $\mathrm{NO}_{2}$ - with a binding energy of $404.4 \mathrm{eV}$ (on VXCO-2) [29]. The other was graphitic-N doped on carbon ( 63\%) [30], further confirming the formation of graphite-like carbon nanoplates after the acid oxidation by Hummers method. This indicated that Hummers method led to pure single doping of G-N on the residual carbon nanoparticle surface due to the freshly exposed perfect graphite surface with minimum defect sites. Defect sites are necessary for other types of N doping [30]. After the following heat treatment at the high temperature of 900 ${ }^{\circ} \mathrm{C}$, Table 1 shows that the $\mathrm{N}$ content on the catalysts decreased from $0.31 \mathrm{wt} \%$ (VXCO-1) and $0.29 \mathrm{wt} \%$ (VXCO-2) to $0.20 \mathrm{wt} \%$ (VXCO-1(900)) and 0.22 wt\% (VXCO-2(900)), which was 33\%
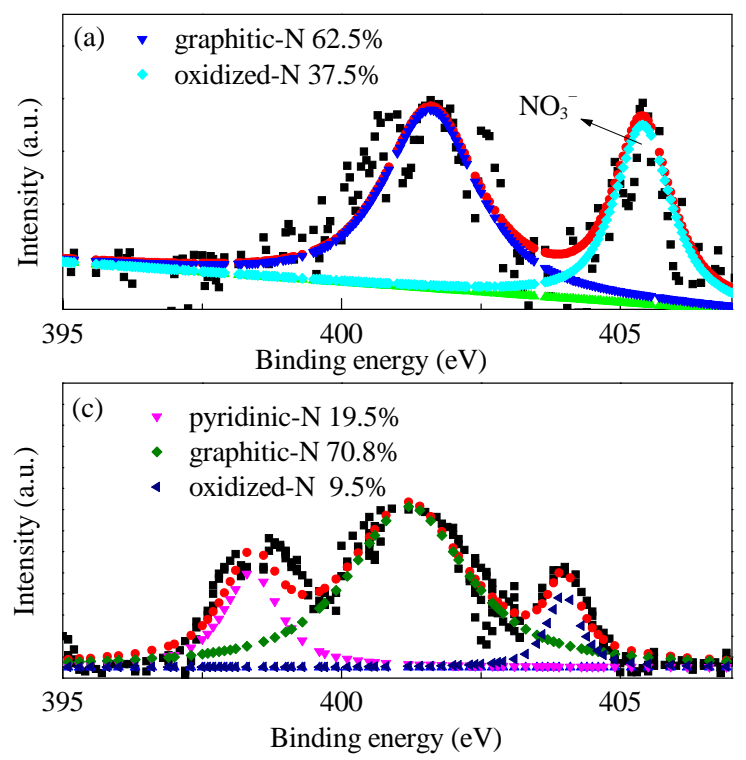

loss of total $\mathrm{N}$ content. This was probably due to the decomposition of $\mathrm{NO}_{3}{ }^{-}$or the breaking of $\mathrm{N}-\mathrm{C}$ bonds at high temperature [25,31]. Interestingly, Fig. 2(c) and (d) show the appearance of $\mathrm{P}-\mathrm{N}$ with a binding energy of 397.8 to $398.3 \mathrm{eV}(\sim 19 \%)$ and $\mathrm{O}-\mathrm{N}$ with a binding energy of 403.7 to $408.0 \mathrm{eV}$ in the form of $\mathrm{C}-\mathrm{N}-\mathrm{O}$ [31]. The disappearance of $\mathrm{NO}_{3}{ }^{-}$and $\mathrm{NO}_{2}{ }^{-}$after the heat treatment indicated that doped $\mathrm{P}-\mathrm{N}$ and $\mathrm{O}-\mathrm{N}(\mathrm{C}-\mathrm{N}-\mathrm{O})$ were mainly formed with adsorbed $\mathrm{NO}_{3}^{-}$or $\mathrm{NO}_{2}^{-}$as the $\mathrm{N}$ precursor. These observations indicated that P-N could only be easily formed at high temperature due to the high energy needed for defect formation on the freshly exposed perfect graphite surface [32]. Interestingly, the data in Table 1 and Fig. 6 further showed that the $\mathrm{N}$ content and chemical states did not change much after the second oxidation, indicating saturated $\mathrm{N}$-doping was achieved under the working conditions of Hummers method.

\subsection{Electrochemical catalytic activity}

Numerous works have clarified that $\mathrm{N}$-doping on carbon materials enhanced the ORR on the catalysts by the formation of new active sites [33-35]. Graphene samples obtained with Hummers method have been extensively used as the support for non-Pt and metal-free ORR catalysts [5,8,33,36-38]. To gain insight into the effect of doped $\mathrm{N}$ on the ORR activity of VXCO-1, VXCO-2, VXC-72(900), VXCO-1(900) and VXCO-2(900), cyclic voltammogram (CV) measurements were performed in 0.1 mol/L KOH solution with oxygen saturation. For comparison, the pristine VXC-72 was also investigated by the same method. As shown in Fig. 7, compared with the pristine VXC-72, the two samples of VXCO-1 and VXCO-2 obtained after the acid oxidation treatment possessed much higher ORR onset potentials (Eonset) and much smaller peak currents. With a following heat treatment, the opposite occurred and compared to VXCO-1 and VXCO-2, the two samples of VXCO-1(900) and VXCO-2(900) obtained after the heat treatment showed lower ORR onset
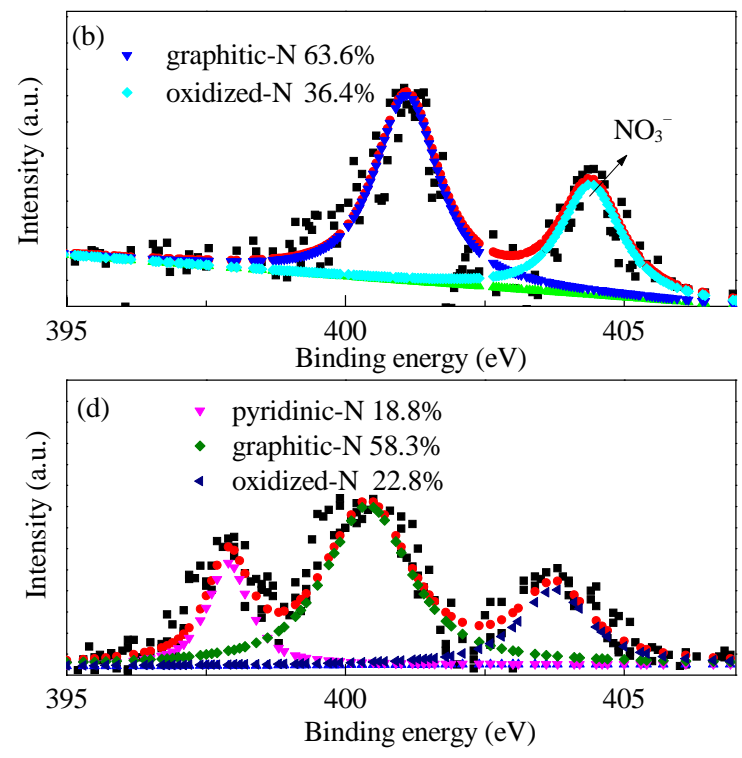

Fig. 6. High resolution XPS spectra for four samples. (a) VXCO-1; (b) VXCO-2; (c) VXCO-1(900); (d) VXCO-2(900). 
potentials ( $\left.E_{\text {onset }}\right)$ and much larger peak currents. Combining the information shown in Fig. 7 with that shown in Table 1 and Fig. 6, the following conclusions were made: (1) the acid oxidation treatment effectively improved the ORR catalytic activity (or increased $E_{\text {onset}}$ ) by graphitic N-doping although the decrease of the $A$ BET led to the decrease of peak current. (2) The following heat treatment have a negative effect on the catalytic activity (indicated by the negative shift of $E_{\text {onset }}$ ) of ORR, which was mainly due to the loss (30\%) of active sites of doped-N although the doubled $A_{\mathrm{BET}}$ led to almost double the peak current. (3) These observations indicated that the trace amount of $\mathrm{N}$ doped on carbon played a very significant role in the improvement of the catalytic activity of ORR on N-based metal-free ORR catalysts. Meanwhile, the $A_{\mathrm{BET}}$ was related to the limiting current obtained at a high overpotential [9]. The value of $E_{\text {onset }}$ was mainly related to the active sites with high activity, while the active sites with low activity contributed in part to the limiting of the peak current at a high overpotential. In addition, the effect of the heat treatment temperature on the ORR catalytic performance of these carbon materials was also researched. As shown in Fig. 8, compared with VXCO-1(800) and VXCO-1(1000), the samples of VXCO-1(900) possessed the highest ORR onset potentials. This indicated that the optimal heat treatment temperature was extremely important to get carbon catalysts containing many active sites with high activity [39].

As shown above, after the heat treatment, some P-N and O-N appeared on VXCO-1(900) and VXCO-2(900), which was probably transformed from G-N during the heat treatment at $900{ }^{\circ} \mathrm{C}$.

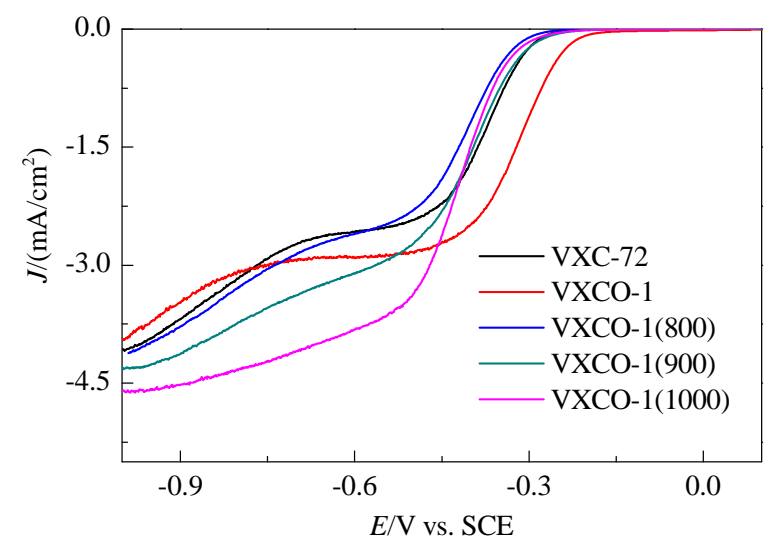

Fig. 8. Disk currents from RRDE measurements of oxygen reduction for VXC-72, VXCO-1, VXCO-1(800), VXCO-1(900) and VXCO-1(1000) in $\mathrm{O}_{2}$-saturated $0.1 \mathrm{~mol} / \mathrm{L} \mathrm{KOH}$. Rotation rate $1600 \mathrm{r} / \mathrm{min}$, scan rate 5 $\mathrm{mV} / \mathrm{s}$.

It is known that the catalytic activity of $\mathrm{O}-\mathrm{N}$ for ORR is very low and approximately on the same level as pure carbon. The catalytic activity of doped P-N for ORR is much higher than that of doped G-N [20]. But in this work, the transformation of G-N to $\mathrm{P}-\mathrm{N}$ did not give an improved ORR catalytic activity in terms of $E_{\text {onset }}$ (Fig. 7). The reason could be due to the loss ( $\left.30 \%\right)$ of total $\mathrm{N}$ content doped on the carbon and that the G-N still dominated the P-N due to the very low content of P-N as shown in Fig. 6.

To further understand the catalytic properties of P-N and G-N doped on the carbon samples, the RRDE technique was
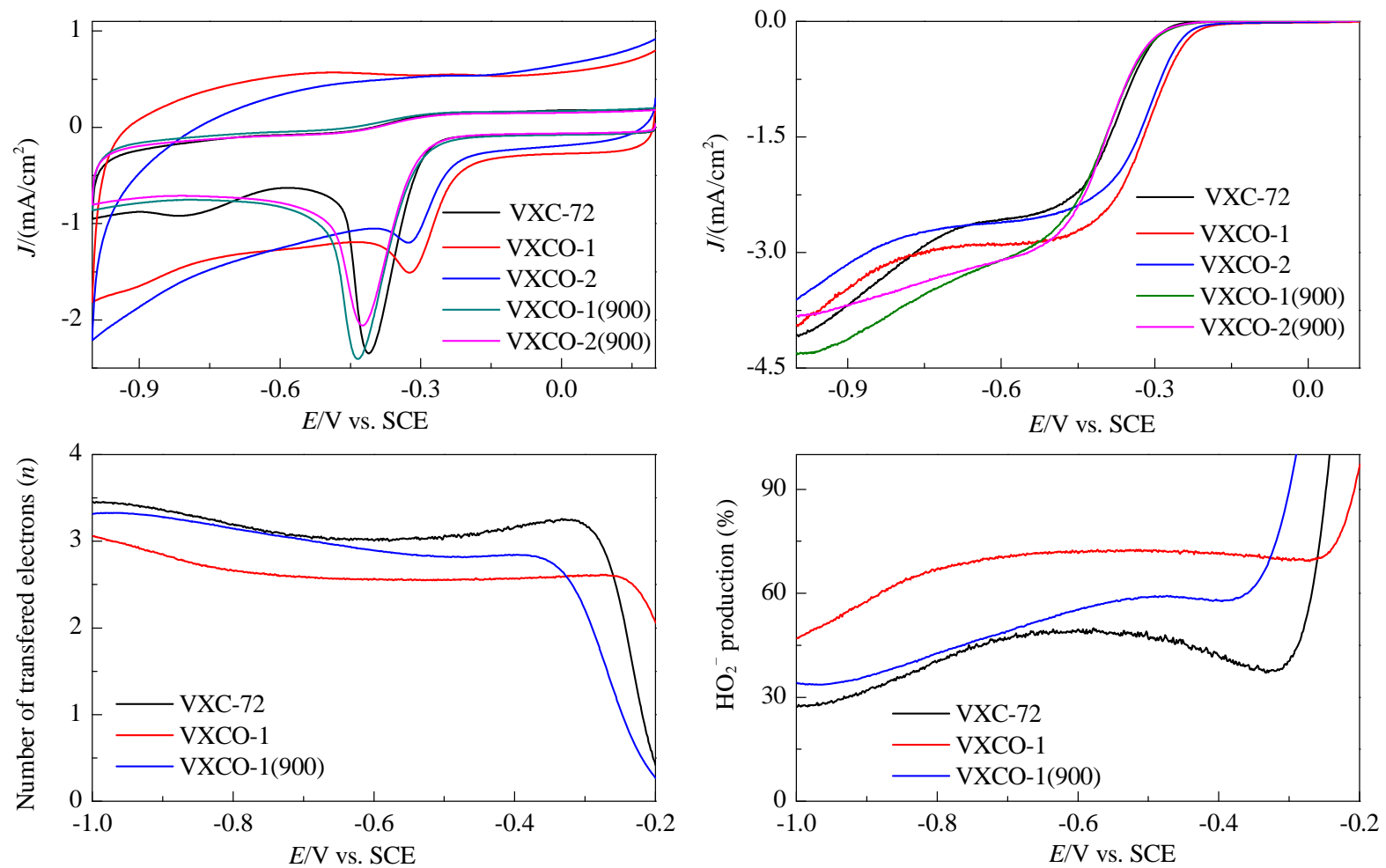

Fig. 7. (a) CV curves of the catalysts in oxygen saturated $0.1 \mathrm{~mol} / \mathrm{L} \mathrm{KOH}$ solution at a scan rate of $50 \mathrm{mV} / \mathrm{s}$. (b) disk currents from RRDE measurements of oxygen reduction for VXC-72, VXCO-1, VXCO-2, VXCO-1(900) and VXCO-2(900) in $\mathrm{O}_{2}$-saturated 0.1 mol/L KOH. Rotation rate: $1600 \mathrm{r} / \mathrm{min}$. Scan rate: $5 \mathrm{mV} / \mathrm{s}$. (c) Number of electrons ( $n$ ) transferred in VXC-72, VXCO-1, VXCO-1(900). (d) $\mathrm{H}_{2} \mathrm{O}_{2}$ yield of VXC-72, VXCO-1, VXCO-1(900). 
used to estimate the transferred electron number $(n)$ and verify the ORR pathway. Fig. 7(b) shows the disk current for the five samples. It shows the same information as that shown by $\mathrm{CV}$ in terms of $E_{\text {onset }}$ and limiting current (Fig. 7). Together with the ring currents, the transferred electron numbers and the yield of $\mathrm{H}_{2} \mathrm{O}_{2}$ at different potentials were obtained. As an example, as shown in Fig. 7(c) and (d) for VXC-72, VXCO-1 and VXCO-1(900), compared with the pristine carbon (VXC-72), the Hummer acid treatment increased the $\mathrm{H}_{2} \mathrm{O}_{2}$ yield or decreased the value of $n$, indicating that ORR on the catalytic sites of doped G-N favored the 2e-pathway with $\mathrm{H}_{2} \mathrm{O}_{2}$ as the product (VXCO-1). This indicated that these oxidized samples were better than pristine VXC-72 for the production of $\mathrm{H}_{2} \mathrm{O}_{2}$ from oxygen reduction in alkaline medium [39]. After the heat treatment at $900{ }^{\circ} \mathrm{C}$, the $\mathrm{H}_{2} \mathrm{O}_{2}$ yield decreased and the value of $n$ increased on VXCO-1(900) compared with VXCO-1. This indicated that the ORR on the newly formed P-N sites favored the 4e pathway with water as the product and decreased the production of $\mathrm{H}_{2} \mathrm{O}_{2}$. However, due to the loss $(30 \%)$ of active sites of doped $\mathrm{N}$ during the heat treatment, the $\mathrm{H}_{2} \mathrm{O}_{2}$ yield of VXCO-1(900) was still lower than that of pristine VXC-72. From the above results, we can see that if the purpose is to get the direct $4 \mathrm{e}^{-}$pathway of ORR with water as the product, one should get pyridinic $\mathrm{N}$ rather than graphite $\mathrm{N}$ on the doped catalysts. But if $\mathrm{H}_{2} \mathrm{O}_{2}$ is the product wanted, then G-N should be the choice for the $\mathrm{N}$ doped metal-free catalysts [22].

\section{Conclusions}

We studied the effects of acid oxidation (Hummers method) and heat treatment on the catalytic activity of the carbon support for ORR. The nitric acid-based oxidation treatment induced $\mathrm{N}$ doping on the carbon support. The heat treatment increased the BET surface area, but the increased BET surface area alone did not improve the catalytic performance of the catalysts. For the $\mathrm{N}$ doped carbon catalytic system, the dopant species and amount of doped $\mathrm{N}$ were more important. The diffusion limiting current was increased by removing impurities in the catalyst pores and enlarging the volume of pores thereby increasing the BET surface area.

\section{References}

[1] N. A. Karim, S. K. Kamarudin, Appl. Energy, 2013, 103, 212-220.

[2] F. Y. Cheng, J. Chen, Chem. Soc. Rev., 2012, 41, 2172-2192.

[3] J. Liang, Y. Zheng, J. Chen, J. Liu, D. Hulicova-Jurcakova, M. Jaroniec, S. Z. Qiao, Angew. Chem. Int. Ed., 2012, 51, 3892-3896.

[4] K. P. Gong, F. Du, Z. H. Xia, M. Durstock, L. M. Dai, Science, 2009, $323,760-764$

[5] S. B. Yang, X. L. Feng, X. L. Wang, K. Müllen, Angew. Chem. Int. Ed., 2011, 50, 5339-5343.

[6] L. Lai, J. R. Potts, D. Zhan, L. Wang, C. K. Poh, C. H. Tang, H. Gong, Z. X. Shen, J. Y. Lin, R. S. Ruoff, Energy Environ. Sci, 2012, 5, 7936-7942.

[7] T. Xing, Y. Zheng, L. H. Li, B. C. C. Cowie, D. Gunzelmann, S. Z. Qiao, S. M. Huang, Y. Chen, ACS Nano, 2014, 8, 6856-6862.

[8] L. T. Qu, Y. Liu, J. B. Baek, L. M. Dai, ACS Nano, 2010, 4, 1321-1326.

[9] C. V. Rao, C. R. Cabrera, Y. Ishikawa, J. Phys. Chem. Lett., 2010, 1, 2622-2627.

[10] L. P. Zhang, Z. H. Xia, J. Phys. Chem. C, 2011, 115, 11170-11176.

[11] Z. H. Sheng, L. Shao, J. J. Chen, W. J. Bao, F. B. Wang, X. H. Xia, ACS Nano, 2011, 5, 4350-4358.

[12] Y. Li, Y. Zhao, H. H. Cheng, Y. Hu, G. Q. Shi, L. M. Dai, L. T. Qu, J. Am. Chem. Soc., 2011, 134, 15-18.

[13] H. B. Li, W. J. Kang, L. Wang, Q. L. Yue, S. L. Xu, H. S. Wang, J. F. Liu, Carbon, 2013, 54, 249-257.

[14] R. L. Liu, D. Q. Wu, X. L. Feng, K. Mullen, Angew. Chem. Int. Ed., 2010, 49, 2565-2569.

[15] H. Kim, K. Lee, S. I. Woo, Y. Jung, Phys. Chem. Chem. Phys., 2011, 13, 17505-17510.

[16] H. Niwa, K. Horiba, Y. Harada, M. Oshima, T. Ikeda, K. Terakura, J. Ozaki, S. Miyata, J. Power Sources, 2009, 187, 93-97.

[17] T. Sharifi, G. Hu, X. Jia, T. Wågberg, ACS Nano, 2012, 6, 8904-8912.

[18] B. Zheng, J. Wang, F. B. Wang, X. H. Xia, Electrochem. Commun., 2013, 28, 24-26.

[19] C. Z. Zhang, R. Hao, H. B. Liao, Y. L. Hou, Nano Energy, 2013, 2, 88-97.

[20] W. Ding, Z. D. Wei, S. G. Chen, X. Q. Qi, T. Yang, J. S. Hu, D. Wang, L. J. Wan, S. F. Alvi, L. Li, Angew. Chem. Int. Ed., 2013, 52, 11755-11759.

[21] W. S. Hummers, R. E. Offeman, J. Am. Chem. Soc., 1958, 80, 1339-1339.

[22] D. H. Guo, R. Shibuya, C. Akiba, S. Saji, T. Kondo, J. Nakarmura, Science, 2016, 351, 361-365.

[23] Y. M. Tan, C. F. Xu, G. X. Chen, X. L. Fang, N. Y. Zheng, Q. T. Xie, Adv.

\section{Graphical Abstract}

Chin. J. Catal., 2016, 37: 1119-1126 doi: 10.1016/S1872-2067(16)62456-7

Catalytic properties of graphitic and pyridinic nitrogen doped on carbon black for oxygen reduction reaction

Jing Liu, Ping Song, Mingbo Ruan, Weilin Xu*

Changchun Institute of Applied Chemistry, Chinese Academy of Sciences;

University of Chinese Academy of Sciences

The G-N site doped on carbon gave the two-electron process and increased the production of $\mathrm{H}_{2} \mathrm{O}_{2}$, while the $\mathrm{P}-\mathrm{N}$ site gave the four-electron process of ORR and decreased the production of $\mathrm{H}_{2} \mathrm{O}_{2}$.
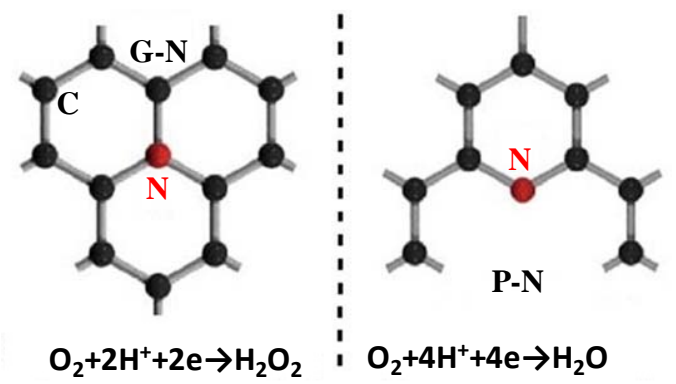
Funct. Mater., 2012, 22, 4584-4591.

[24] T. Soboleva, X. S. Zhao, K. Malek, Z. Xie, T. Navesin, S. Holdcroft, Appl. Mater. Interfaces, 2010, 2, 375-384.

[25] Y. T. Ma, H. Wang, S. Ji, J. Goh, H. Q. Feng, R. F. Wang, Electrochim. Acta, 2014, 133, 391-398.

[26] H. Zamora, P. Canizares, M. A. Rodrigo, J. Lobato, Fuel Cells, 2015, 15, 375-383.

[27] A. A. Arie, J. K. Lee, J. Nanosci. Nanotechnol., 2011, 11, 6569-6574.

[28] M. A. Andres, R. Miguez, M. A. Corcuera, I. Mondragon, Polym. Int 1994, 35, 345-353.

[29] J. Baltrusaitis, P. M. Jayaweera, V. H. Grassian, Phys. Chem. Chem. Phys., 2009, 11, 8295-8305.

[30] G. Wu, K. L. More, C. M. Johnston, P. Zelenay, Science, 2011, 332, 443-447.

[31] X. J. Sun, P. Song, Y. W. Zhang, C. Liu, W. L. Xu, W. Xing, Sci. Rep., 2013, 3, 2505/1-2505/5.
[32] L. Li, S. Reich, J. Robertson, Phys. Rev. B, 2005, 72, 184109/1-184109/10.

[33] D. C. Wei, Y. Q. Liu, Y. Wang, H. L. Zhang, L. P. Huang, G. Yu, Nano Lett., 2009, 9, 1752-1758.

[34] W. M. Li, J. Wu, D. C. Higgins, J. Y. Choi, Z. W. Chen, ACS Catal., 2012, 2, 2761-2768.

[35] Z. Y. Mo, R. P. Zheng, H. L. Peng, H. G. Liang, S. J. Liao, J. Power Sources, 2014, 245, 801-807.

[36] M. Wu, C. Cao, J. Z. Jiang, Nanotechnology, 2010, 21, 505202/1-505202/6.

[37] Y. Y. Liang, Y. G. Li, H. L. Wang, J. G. Zhou, J. Wang, T. Regier, H. J. Dai, Nat. Mater., 2011, 10, 780-786.

[38] G. Wu, H. T. Chung, M. Nelson, K. Artyushkova, K. L. More, C. M. Johnston, P. Zelenay, ECS Trans., 2011, 41, 1709-1717.

[39] P. Song, Y. W. Zhang, J. Pan, L. Zhuang, W. L. Xu, Chem. Commun., 2015, 51, 1972-1975.

\section{氮掺杂的碳材料中石墨化氮和吡啶氮对氧还原反应的催化特性}

刘 京 ${ }^{\mathrm{a}, \mathrm{b}}$, 宋 平 ${ }^{\mathrm{a}}$, 阮明波 ${ }^{\mathrm{a}}$, 徐维林 ${ }^{\mathrm{a}}$ *

a中国科学院长春应用化学研究所电分析化学国家重点实验室, 吉林省低碳化学能源重点实验室, 吉林长春 130022

b国科学院大学, 北京 100049

摘要: 目前, 开发高效的阴极氧还原反应 (ORR) 电催化剂是实现燃料电池和金属-空气电池商业化发展急需完成的目标. 在过去的几十年中, 人们在探索廉价高效的 ORR 电催化剂 (如 $\mathrm{N}$ 掺杂的非金属及非铂电催化剂) 领域做了广泛的研究. 在 $\mathrm{N}$ 掺杂的碳基 ORR 催化剂中, 已知的 $\mathrm{N}$ 基活性位点主要分为四类, 即吡啶类氮 (P-N)、吡咯类氮 (Py-N)、石墨化氮 (G-N) 和氧化类氮 $(\mathrm{O}-\mathrm{N})$. 尽管人们对这四种类型氮的活性位点做了大量的研究, 但是它们在催化反应中起到的 ORR 催化作用 以及催化机理和活性位点本身结构的关系仍不够明确. 早期的研究中有人认为 P-N 或者 Py-N 是 ORR 催化活性位点, 也 有人认为是 G-N 起作用. 最近也有研究表明, P-N 和 G-N 都是 ORR 催化活性位点, 只是在 ORR 中所起的催化能力不同. 因此, 很有必要认清这些问题.

本文通过 Hummer 法酸性氧化一次和两次碳黑 Vulcan XC-72(VXC-72) 以及随后高温热处理，制备了一系列 ORR 催 化剂 VXCO-1, VXCO-2, VXCO-1(900) 和 VXCO-2(900), 采用场发射扫描电子显微镜 (SEM), $\mathrm{N}_{2}$ 吸附脱附法, 元素分析仪 (EA), $X$ 射线光电子能谱 (XPS), 拉曼光谱仪 (Raman), X 射线衍射能谱 (XRD), 电化学循环伏安法和线性伏安法测试等手 段研究 Hummers 法酸氧化和高温热处理对 VXC-72 形貌组成的影响, 以及这些碳基中成分和其催化 ORR 能力的关系.

SEM 结果表明, Hummer 法酸性氧化处理 VXC-72 一次和两次后可以逐层剥落其最外边的碳层结构, 最终得到表面光 滑的类片层状结构的碳材料 (VXCO-1 和 VXCO-2). 这种表面光滑的类片层状结构的碳材料比表面积大于处理前的 VXC-72, 而高温热处理之后的碳材料 (VXCO-1(900) 和 VXCO-2(900)) 由于类石墨层碎片结构蒸发损失暴露出更多内部 的微孔和介孔结构使比表面积增加. Raman 和 XRD 结果表明, 氧化处理使碳材料的石墨化程度增加, 而高温热处理则降 低了其石墨化程度.

EA 和 XPS 结果表明, Hummer 法酸性氧化处理可以使在碳材料中掺入的 $\mathrm{N}$ 以石墨化的为主, 高温热处理却使得石墨 化氮转变为吡啶类的氮. ORR 结果发现, 活性的石墨化氮倾向于使 ORR 反应经历两电子过程, 从而生成 $\mathrm{H}_{2} \mathrm{O}_{2}$ 为主要产 物; 而吡啶类氮的活性位点更倾向于使 ORR 反应经过四电子过程, 主产物是水. 该结果有助于新型碳基氧还原催化剂的 设计和分析.

关键词: 碳黑; 高温热处理; 氧还原反应; 氮掺杂; 碳基催化剂

收稿日期: 2016-03-20. 接受日期: 2016-05-11. 出版日期: 2016-07-05.

*通讯联系人. 电话/传真: (0431)85262848; 电子信箱: weilinxu@ciac.ac.cn

基金来源：国家重点基础研究发展计划(973 计划，2014CB932700，2012CB932800); 国家自然科学基金(21422307, 21303180, 21433003, 21503212, 21503211); 国家中组部“千人计划”人才项目.

本文的英文电子版由Elsevier出版社在ScienceDirect上出版(http://www.sciencedirect.com/science/journal/18722067). 